\title{
Application of Trichoderma harzianum T10 Liquid Formula Based on Soybean Flour Against Cucumber Seedlings Damping-Off (Pythium sp.)
}

\author{
Loekas Soesanto*, Atika Nur Solikhah, Endang Mugiastuti, and Woro Sri Suharti \\ Agriculture Faculty, University of Jenderal Soedirman \\ Jl. dr. Suparno 73, Purwokerto 53123 telp/faks. (+62) 0281-638791
}

\begin{abstract}
ARTICLE INFO

Keywords:

cucumber

damping-off

liquid formula

soybean flour

Trichoderma harzianum

Article history:

Received: Jun 17, 2020

Accepted: Jun 27, 2020

Published Jun 29, 2020

*Corresponding author:

E-mail: lukassusato26@gmail.com

(Proper concentration of soybean flour in the liquid formulation for Trichoderma harzianum T10 growth, was investigated to improve suppression efftivety on damping-off and growth of cucumber seedlings. A randomized completely design was used in in vitro test with five treatments and five replications. The treatments were T. harzianum T10 cultured in Potato Dextrose Broth (control), in liquid information based on soybean fluor at concentration $1,2,3$ or $4 \%$. A randomized block design was used in in planta test with six treatments and five replications. Variables observed were conidia density, incubation period, disease incidence, area under the disease progress curve (AUDPC), maximum potentially growth, germination percentage, crop height, root fresh weight, shoot fresh weight, and root length. The results of the experiment showed that the best liquid formulation for T. harzianum T10 growth was the use of soybean fluor at concentration of $2 \%$ resulting in conidia density as $67,10 \%$ compared to PDB. The formulation could suppress the disease incidence, decreasesd AUDPC value, increased root fresh weight, shoot fresh weight, and root length as $67 \%, 66 \%, 57 \%, 44 \%$, and $42 \%$, respectively, as compared to those in control.
\end{abstract}

\section{INTRODUCTION}

Cucumber (Cucumis sativus L.) is a plant that produces fruit, which can be eaten both fresh and further processed (Andrie et al., 2015). Cucumber plants can be cultivated in temperate and tropical environments. Moreover, it is said that cucumber is to be native to many regions of the world (Mortimore, 2015).

Based on data from the Central Statistics Agency (2017), the development of cucumber production in Indonesia in 2013 reached 491,636 tons / year, but in 2014-2016 the production of cucumber plants decreased respectively, namely 477,989, 447,696 and 430,218 tons/year. One of the causes of the decline is due to of disease in cucumber plants. According to Sutton et al. (2006), barriers in cucumber cultivation include damping-off, which often harms cucumber planters. Efforts to control plant pathogens have been carried out, both with the use of resistant plants although not always available (Koike et al., 2000; Weller et $a l, 2002$ ) or with synthetic pesticides; but the impact is not good for the environment or humans (Aktar et al., 2009; Zaidi et al., 2011).

One alternative to anticipate these impacts is through biological control, by utilizing biological

ISSN: 1410-3354 / e-ISSN:2615-7136

Cited this as: Soesanto, L., A.N. Solikhah, E. Mugiastuti, and W.S. Suharti. 2020. Application of Trichoderma harzianum T10 liquid formula based on soybean flour against cucumber seedlings damping-off (Pythium sp.). Akta Agrosia 23(1):11-18. 
control agents (Shafique et al., 2016). One of the biological agents is Trichoderma sp. that has been widely used to control plant pathogenic microbes (Kumar et al., 2017). Trichoderma sp. has antagonistic properties to pathogens in the form of space and nutrition competition, mycoparasites and antibiosis (Benítez et al., 2005).

Biofungicide Trichoderma sp. is widely developed in the form of ssolid ubstrates to be applied in the field be, but liquid form might be more efficient. Solid substrate form is still not practical and efficient for large plantation scale, so it needs to be formulated according to the needs in the field (Nurhidayati et al., 2015), such as liquid form. The formulation aims to facilitate application, transportation, determination of concentration, production costs, storage capability, environmental conditions, and efficacy (Gašić and Tanović, 2013).

Growth of Trichoderma sp. require food ingredients, such as carbohydrates as an energy source during their growth and development (Uruilal et al., 2012). Soybean flour is a semifinished material that can be used as a carrier and as an ingredient that can enrich nutrients such as carbohydrates (Gozalli, 2015). The use of soy flour as the main ingredient in making liquid formulas for $T$. harzianum propagation is still very rarely done.

The research objective was to determine the right concentration of soy flour in the preparation of liquid formula for the growth of $T$. harzianum T10, its effect on suppression of seedling diseases, and on the growth of cucumber plants.

\section{MATERIALS AND METHODS}

\section{Preparation of T. harzianum T10}

T. harzianum T10 isolates (Soesanto et al., $2019 b$ ) were propagated on the PDA medium aseptically and incubated for 5-7 days. FSubsequently the fungus was propagated on broken corn medium and incubated at room temperature for 10-12 days (Heydari and Pessarakli, 2010).

\section{Preparation of Pythium sp.}

Pythium sp.was isolated from symptomatic chilli seedlings. The symptomatic plant was removed and the affected part was cut and then surface sterilized and grown on a PDA. Following the growth of the fungi, they were microscopically observed then purified and propagated into a new PDA and incubated at room temperature for 2-5 days (Sutton et al., 2006).

\section{Preparation of liquid media based on soybean fluor and Potato Dextrose Broth (PDB)}

Liquid medium was made to five treatments. The control treatment used PDB, the soy fluor treatment with $10,20,30$, and $40 \mathrm{~g}$ of soy flour with each concentration treatment added $10 \mathrm{~g} / \mathrm{L}$ of sugar in 1 liter of water. Flour liquid medium was made by mixing soy flour and sugar according to treatment, then heating it until it boils (Soesanto et al., 2015). Medium PDB was made by peeling potatoes and weighed $200 \mathrm{~g}$, followed by boiled in $1000 \mathrm{~mL}$ water. The boiled water was put into a beaker and the volume was returned to $1000 \mathrm{~mL}$. After that, 20 grams of dextrose was put into a beaker and cooked again until it boiled. Each medium, as much as $100 \mathrm{~mL}$ that has been made was put into a $140 \mathrm{~mL}$ bottle, covered with aluminum foil and then coated with paper and tied using a rubber band. All mediums were then sterilized using an autoclave at $121{ }^{\circ} \mathrm{C}, 15$ psi pressure for 30 minutes.

\section{Development formula}

The liquid medium of soy flour and sterile PDB was added with $1 \mathrm{~mL} T$. harzianum T10 with a density of $10^{6}$ conidia $\mathrm{mL}^{-1}$. Furthermore, each treatment was shaken with a $150 \mathrm{rpm}$ orbital shaker at room temperature for 7 days (Soesanto et al., 2019a).

\section{In vitro test}

In vitro testing was carried out using randomized completely design with five treatments and five replicates so that there were 25 experimental units. The treatments consisted of T. harzianum $\mathrm{T} 10$ in $\mathrm{PDB}$, in liquid formula containing $1,2,3$, and $4 \%$ of soy flour.

\section{In planta experiment}

In planta testing was carried out using arandomiszed block design with six treatments 
and five replicates so that there were 30 experimental units, each with four potted plants, so that there were 120 experimental pots. The treatments consisted of control, $T$. harzianum $\mathrm{T} 10$ in $\mathrm{PDB}$, in liquid formula of soy flour $1,2,3$, and $4 \%$ soy flour. The experiment was carried out by applying liquid formula to plants in the experimental pot. The planting media in the polybag was made a planting hole, placed one cork drill $(12.7 \mathrm{~mm}$ diameter) culture of Pythium sp. then covered with thin soil and on top of it was placed cucumber seeds (Inácio et al., 2017). A total of $10 \mathrm{~mL}$ T. harzianum T10 with a density of $10^{6}$ conidia $\mathrm{mL}^{-1}$ was poured after the cucumber seeds were thinly covered with soil medium and manure (Soesanto et al., 2019a).

\section{Variable observed}

Observed in this study were conidia density, pathosystem components (incubation period, disease incidence, and Area Under Disease Progress Curve (AUDPC) values, and cucumber growth components (maximum growth potential, germination capacity, plant height, roots fresh weight, shoot fresh weight, and root length).

Conidia density was calculated using a microscope with a magnification of $100 \mathrm{x}$ on the haemocytometer. The calculation was repeated four times and the density was calculated using formula: $S=[(\mathrm{t} \times \mathrm{d}) /(\mathrm{b} \times 0.25)] \mathrm{x}$ 106 , where $S=$ number of conidia per gram of media culture, $t=$ the number of conidia calculated on the count media, $\mathrm{d}=$ degree of dilution, $\mathrm{n}=$ the number of small boxes observed (i.e. $5 \times 16$ $=80$ small boxes), and $0,25=$ correction factor (Akagi et al., 2015).

The incidence of lodging diseases in cucumber were calculated using the following equation (Noordzij et al. (2010), : DI $=[\mathrm{b} / \mathrm{N}] \mathrm{x}$ $100 \%$. Note: $\mathrm{DI}=$ percentage of shoot disease $(\%), \mathrm{n}=$ number of plants affected by Pythium sp., and $\mathrm{N}=$ number of plants observed.

Effectiveness of disease suppression was calculated to determine the ability of treatment in suppressing seedling disease compared to those in untreated control. The formula for calculating the effectiveness of disease control, according to Alves et al. (2015), was:
Effectiveness $=\underline{X}_{\text {control }}-X_{\text {treatment }} \times 100 \%$

Note: $\mathrm{X}_{\text {treatment }}=\mathrm{DI}$ on treatment and $\mathrm{X}_{\text {control }}=$ DI on control.

The rate of disease progression over time was calculated using the AUDPC formula as follows (Jeger and Viljanen-Rollinson, 2001):

where: AUDPC: Disease progression curve ( $\%$ -days), $\mathrm{Y}=$ severity of disease at time $\mathrm{t}, \mathrm{i}=$ number of days after planting, time of observation to $\mathrm{i}, \mathrm{n}=$ total number of measurements.

\section{Data analysis}

Observed data were analyzed for variance (F test) at an error level of 5\%. If there were significant differences, then the Honesty Significant Difference (HSD) test was further applied at an error level of 5\%.

$$
\mathrm{AUDPC}=\sum_{i=0}^{n-1}\left(\frac{\mathrm{Yi}+\mathrm{Yi}+1}{2}\right) \cdot\left(\mathrm{t}_{i+1}-t_{i}\right)
$$

\section{RESULTS AND DISCUSSION}

\section{Population density of T. harzianum T10 in soy fluor liquid formula}

Based on the results of the statistical analysis in Table 1, the best concentration for growth and development of T. harzianum T10 is at 2\% soy flour concentration. These results are shown from the observation of the amount of T. harzianum T10 conidiat $2 \%$ flour concentration increased by $67.10 \%$ compared to PDB.

The liquid media used in the propagation of T. harzianum T10 was based on soy flour (GASOL), which contains carbohydrates of $6.85 \mathrm{~g}$ carbohydrates and $7.22 \mathrm{~g}$ protein. The nutritional content in soy flour is supportive for the growth and development of T. harzianum T10. This is in accordance to the opinion of Zehra et al. (2017), that it is important to consider various parameters affecting their growth and sporulation when planning the application 
Table 1. Conidia density of T. harzianum T10

\begin{tabular}{lc}
\hline Treatment & $\begin{array}{c}\text { Conidia density } \times 10^{7} \text { conidia } \\
\mathrm{mL}^{-1}\end{array}$ \\
\hline PDB & $3.26 \mathrm{a}$ \\
Soy fluor $1 \%$ & $5.36 \mathrm{ab}$ \\
Soy fluor $2 \%$ & $9.91 \mathrm{~b}$ \\
Soy fluor 3\% & $5.66 \mathrm{ab}$ \\
Soy fluor 4\% & $7.94 \mathrm{ab}$ \\
\hline
\end{tabular}

Note: Numbers followed by different letters show significant differences in Tukey test with an error rate of $5 \%$. Data were analyzed after they were transformed to $\sqrt{\mathrm{x}}$

of antagonistic Trichoderma strains for the purpose of biological control. Uruilal et al. (2012) revealed that the growth of Trichoderma $s p$. was strongly influenced by carbohydrate content, such as monosaccharides, disaccharides and polysaccharides used as energy sources for growth.

High or low number of T. harzianum T10 conidia was influenced nutrient content in the form of carbohydrates and cellulose as a food source (Gusnawaty et al., 2017). The amount of conidia in the liquid formulation of soy flour $2 \%$ concentration was higher than the concentration of soybean flour 3 and 4\%. At concentrations of 3 and $4 \%$ liquid formula, soy flour was very thick, so that it will affect the solubility of oxygen as an energy source in the growth and development of $T$. harzianum $\mathrm{T} 10 \mathrm{in}$ liquid formulas when shaking. T. harzianum produces conidia during its growth and development, so that if oxygen is sufficient, then the amount of conidium produced is also great. Said (2010) states that stirring or shaking the liquid medium can increase oxygen concentration in the medium; the faster stirring speed, the higher oxygen concentration in the culture medium is .

The amount of conidia in the liquid formula $2 \%$ is more density than the 3 and $4 \%$ concentration. It is also suspected because the water in the media is bound by soy flour, so there is no available water for $T$. harzianum T10 growth. This statement is supported by Kredics et al. (2004) that, T. harzianum requires water in the available form on for mycelial growth and extracellular enzyme systems. Napitupulu et al. (2013), claimed that soy flour is one of the binders that can increase the binding capacity of water in food ingredients because in soy flour there are starches and proteins that can bind water.

\section{Application of T. harzianum T10 liquid formula on pathosystem components}

\section{Incubation period}

The analysis results in Table 2 show that all treatments were not significantly different in term of the incubation period. The absence of a significant effect of the given treatment is thought to be caused by environmental conditions such as temperatures that support the development of the fungus Pythium sp. so the the duration from inoculation of pathogens until symptoms appear relatively uniform.

Table 2. The effect of treatments on pathosystem components

\begin{tabular}{lccc}
\hline Treatments & $\begin{array}{c}\text { Incubation } \\
\text { period } \\
(\text { dai })\end{array}$ & $\begin{array}{c}\text { Disease } \\
\text { incidence } \\
(\%)\end{array}$ & $\begin{array}{c}\text { AUDPC } \\
\text { value } \\
(\% \text {-days })\end{array}$ \\
\hline Control & $4.6 \mathrm{a}$ & $90 \mathrm{a}$ & 1,180 \\
PDB & $3.6 \mathrm{a}$ & $65 \mathrm{ab}$ & 965 \\
Soy fluor 1\% & $5.2 \mathrm{a}$ & $50 \mathrm{ab}$ & 700 \\
Soy fluor 2\% & $6.0 \mathrm{a}$ & $30 \mathrm{~b}$ & 400 \\
Soy fluor 3\% & $3.6 \mathrm{a}$ & $40 \mathrm{~b}$ & 510 \\
Soy fluor 4\% & $3.8 \mathrm{a}$ & $40 \mathrm{~b}$ & 530
\end{tabular}

Note: Numbers followed by the same letter in the same column show no significant difference in HSD test with an error level of $5 \%$. The incubation period data was transformed $\sqrt{\mathrm{x}}$ and the disease incidence data was transformed in $\arcsin \sqrt{ } \%$. dai $=$ days after inoculation.

Characterising the incubation period of a pathogen-host system relies on the ability to determine and relate the relative development of host infectiousness and pathology influenced by host age or environmental variables (Leclerc et al., 2014). The temperature in the experimental field when conducting the research was $28^{\circ} \mathrm{C}$. According to Nzungize et al (2012), Pythium can thrive at temperatures of $25-36^{\circ} \mathrm{C}$. In addition, the different incubation periods are thought to be caused by the lack of application of $T$. harzianum T10 raw secondary metabolites (produced from density of $10^{6}$ conidia $\mathrm{mL}^{-1}$ ), although it appears in the Table 2 of application that the raw secondary metabolites symptoms appear longer than control. This is consistent with the 
results of the study that the two highest densities $\left(10^{8}\right.$ and $10^{10}$ spore $/ g$ soil $)$ of both $T$. harzianum and $T$. viride showed persistent and significant $(\mathrm{P} \leqslant 0.05)$ effects $(\mathrm{Al}-\mathrm{Hazmi}$ and TariqJaveed, 2016).

\section{Disease incidence}

Liquid formula of $T$. harzianum T10 significantly affected Phytium incidence (Table 2 ). Concentration of $2 \%$ soy flour in the liquid formula was the best concentration in reducing the disease incidence by $66.67 \%$ as compared to control. These results might indicate that the $T$. harzianum T10 raw secondary metabolites is able to control seedling disease in cucumber. This indication is based that under soy flour $2 \%$ formula, the number of $T$. harzianum spores produced is very large, i.e., $67.10 \%$ compared to those under PDB, so that the raw secondary metabolites of $T$. harzianum T10 produced to suppress the development of pathogens are also numerous. According to Vinale et al. (2014), raw secondary metabolites from $T$. harzianum in the form of antibiotics, enzymes, hormones and toxins can inhibit the development of pathogens in plant tissues, with various mechanisms. The enzymes produced include protease, cellulase, selobiase, 1,3- $\beta$-glucanase and chitinase. Low concentrated enzymes diffuse into the pathogenic fungal cell walls and damage the pathogenic fungal cell walls. Chitinase enzyme will hydrolyze $\beta-1,4$ bonds in chitin and chitin oligomer. Chitin is an important component of cell walls of some pathogenic fungi. Köhl et al. (2019) added that the enzyme produced by $T$. harzianum was able to dissolve the pathogenic fungal cell walls.

\section{The value of the area under the development of pathogenic curve curve} (AUDPC)

The lower the AUDPC value, the more effective the treatment is in controlling plant pathogens (Hanudin et al., 2013). .Based on the Table 2, cucumber treated with $T$. harzianum T10 had lower AUDPC values as compared to those in control. The AUDPC value on the control was $1,180 \%$-days for \pm 3 weeks, whereas the lowest AUDPC value was at the treatment of raw secondary metabolites in the liquid formula of soy flour $2 \%$ as $400 \%$-days for \pm 3 weeks or decreasing $66,10 \%$ the value as compared to those in control. The low AUDPC values in all treatments compared to controls might be mainly because the raw secondary metabolites $T$. harzianum $\mathrm{T} 10$ can reduce the incidence of Pythium seedling disease in cucumber. T. harzianum produced in the form of antibiotics, enzymes, hormones and toxins (Vinale et al., 2014). Central to the biocontrol activity of Trichoderma spp. is the production of secondary metabolites, which are natural compounds that aid the producing organism in survival and basic functions such as symbiosis, competition and differentiation (Shwab and Keller, 2008).

\section{Application of $T$. harzianum T10 liquid formula on plant growth components Maximum growth potential, germination ability, and crop height}

The results showed that all treatments did not significantly affect germination, maximum growth potential, and crop height. The treatment given did not affect the germination of cucumber though it showed that PDB had a germination rate lower than other soy fluor treatments except the soy flour concentration of $3 \%$.

This is presumably because the seeds planted have good vigor. Good vigor is supported because of good aeration in control and treatment plants so that given raw secondary metabolites do not have a significant effect. These results are in line with the opinion of Finch-Savage and Bassel (2016) explained that seeds that are able to grow normally, even though natural conditions are not optimum are called seeds that have good vigor. In addition, Trichoderma sp. produced growth hormones. According to Jaroszuk-Ściseł et al. (2019), Trichoderma sp. synthezied not only IAA and gibberellic acid (GA) but also the 1aminocyclopropane-1-carboxylic acid (ACC) deaminase (ACCD) enzyme regulating ethylene production by plant in the liquid culture. It is suggested that hormones produced by $\mathrm{T}$. harzianum $\mathrm{T} 10$ is low influenced by its conidia density. Phytohormone compounds produced must be in a very high microbial population density, the environmental factors influences the speed of growth, whereas antagonistic microbes grow faster in artificial media than in soil media (Egamberdieva et al., 2017). 
Table 3. The effect of treatments on cucumber growth components

\begin{tabular}{lccclll}
\hline Treatments & $\begin{array}{c}\text { Maximum } \\
\text { growth poten- } \\
\text { tial (\%) }\end{array}$ & $\begin{array}{c}\text { Germination } \\
\text { ability }(\%)\end{array}$ & $\begin{array}{c}\text { Crop } \\
\text { height }(\mathrm{cm})\end{array}$ & $\begin{array}{l}\text { Root fresh } \\
\text { weight }(\mathrm{g})\end{array}$ & $\begin{array}{c}\text { Crop fresh } \\
\text { weight }(\mathrm{g})\end{array}$ & $\begin{array}{l}\text { Root len- } \\
\text { grth (cm) }\end{array}$ \\
\hline Control & $95 \mathrm{a}$ & $95 \mathrm{a}$ & $10.74 \mathrm{a}$ & $0.55 \mathrm{a}$ & $3.54 \mathrm{a}$ & $11.30 \mathrm{a}$ \\
PDB & $100 \mathrm{a}$ & $90 \mathrm{a}$ & $12.92 \mathrm{a}$ & $0.74 \mathrm{ab}$ & $4.55 \mathrm{ab}$ & $13.79 \mathrm{ab}$ \\
Soy fluor 1\% & $95 \mathrm{a}$ & $100 \mathrm{a}$ & $14.18 \mathrm{a}$ & $1.13 \mathrm{ab}$ & $6.19 \mathrm{ab}$ & $16.96 \mathrm{ab}$ \\
Soy fluor 2\% & $100 \mathrm{a}$ & $100 \mathrm{a}$ & $14.80 \mathrm{a}$ & $1.29 \mathrm{~b}$ & $6.30 \mathrm{~b}$ & $19.42 \mathrm{~b}$ \\
Soy fluor 3\% & $95 \mathrm{a}$ & $95 \mathrm{a}$ & $13.75 \mathrm{a}$ & $0.75 \mathrm{ab}$ & $4.57 \mathrm{ab}$ & $15.29 \mathrm{ab}$ \\
Soy fluor 4\% & $100 \mathrm{a}$ & $100 \mathrm{a}$ & $13.65 \mathrm{a}$ & $0.99 \mathrm{ab}$ & $5.64 \mathrm{ab}$ & $16.80 \mathrm{ab}$ \\
\hline
\end{tabular}

Note: Numbers followed by the same letter in the same column show no significant difference in HSD with an error level of $5 \%$.

\section{Root and crop fresh weight, and root length}

Liquid formula significantly increased root fresh weight, canopy fresh weight, and root length (Table 3 ). The liquid formula of $2 \%$ soy flour was the best formulation, increasing root fresh weight by $57.36 \%$, canopy fresh weight by $43.81 \%$, and root length $41.81 \%$ as compared to control. The increase may be due mainly to interactions between the raw secondary metabolites of $T$. harzianum $\mathrm{T} 10$ and plants. According to Jaroszuk-Ściseł et al. (2019), Trichoderma sp. can produce active substances such as the auxin hormone which can stimulate the formation of lateral roots. Baihaqi et al. (2013) said that good root growth will support the plant's need for more nutrients, making it possible to increase the number of root and crop fresh weight. Trichoderma spp. significantly increased plant height $(<0.001)$, leaf number $(0.001)$, root length $(0.007)$, root fresh weight $(<0.001)$ and root dry weight $(<0.001)$ compared to the untreated plants (control) on mustard growth (Brassica juncea L.) (Roslee et al., 2017). It is supported by Azarmi et al. (2011) that seed germination rate was not affected by Trichoderma application, but shoot height, shoot diameter, shoot fresh and dry weight and root fresh and dry weight in tomato seedlings were interestingly ( $\mathrm{p} \leq$ 0.05 ) increased when sown in Trichoderma sp. $\mathrm{T}$ and T. harzianum $\mathrm{T} 969$ fortified soil and when compared to the control.

\section{CONCLUSION}

The right concentration of soy flour in making liquid formula for the growth of $T$. harzianum $\mathrm{T} 10$ is $2 \%$ indicated by the amount of $T$. harzianum conidia, $67.10 \%$ greater than those in PDB. T. harzianum $\mathrm{T} 10$ in the liquid formula containing $2 \%$ soybean flour suppressed the disease incidence and decrease AUDPC value at $66.67 \%$ and $66.10 \%$, respectively, as compared to those in control. In addition, $T$. harzianum 10 in those liquid formula increased root fresh weight, crown fresh weight, and root length by $57.36 \%$, $43.81 \%$, and $41.81 \%$, respectively, as compared to those control plants.

\section{REFERENCES}

Akagi, A., C. Jiang, and H. Takatsuji. 2015. Magnaporthe oryzae inoculation of rice seedlings by spraying with a spore suspension. Bio-protocol 5(11): e1486. doi: 10.21769/BioProtoc. 1486.

Aktar, W., D. Sengupta, and A. Chowdhury. 2009. Impact of pesticides use in agriculture: Their benefits and hazards. Interdisciplinary Toxicology 2(1): 1-12. doi:10.2478/v10102-009-0001-7.

Al-Hazmi, A.S. and M. TariqJaveed, 2016. Effects of different inoculum densities of Trichoderma harzianum and Trichoderma viride against Meloidogyne javanica on tomato. Saudi Journal of Biological Sciences 23(2): 288-292. doi: 10.1016/ j.sjbs.2015.04.007.

Alves, K.F., D. Laranjeira, M.P.S. Câmara, C.A.G. Câmara, snd S.J. Michereff. 2015. Efficacy of plant extracts for anthracnose control in bell pepper fruits under controlled conditions. Horticultura Brasileira 33(3). 
doi: 10.1590/S0102-053620150000300009.

Andrie, K.L., M. Napitupulu, dan N. Jannah. 2015. Respon tanaman mentimun (Cucumis sativus L.) terhadap jenis POC dan konsentrasi yang berbeda. J. Agrifor 14(1): 15-26.

Azarmi, R., B. Hajieghrari, and A. Giglou. 2011. Effect of Trichoderma isolates on tomato seedling growth response and nutrient uptake. African Journal of Biotechnology 10(31): 5850-5855. doi: 10.5897/AJB10.1600.

Badan Pusat Statistik. 2017. Produksi Mentimun di Indonesia, 2013-2016. Badan Pusat Statistik dan Direktorat Jenderal Hortikultura. (On-line) $\quad$ https:// www.bps.go.id/subject/55/

hortikultura.html\#subjekViewTab5 diakses pada tanggal 30 Januari 2018.

Benítez, T., A.M. Rincón, M.C. Limón, and A.C. Codón. 2005. Biocontrol mechanism of Trichoderma strains. International Microbiology 7(4): 249-60.

Egamberdieva, D., S.J. Wirth, A.A. Alqarawi, E.F. Abd_Allah, and A. Hashem. 2017. Phytohormones and beneficial microbes: Essential components for plants to balance stress and fitness. Front Microbiol. 8: 2104. doi: 10.3389/fmicb.2017.02104.

Finch-Savage, W.E. and G.W. Bassel. 2016. Seed vigour and crop establishment: extending performance beyond adaptation. Journal of Experimental Botany 67(3): 567591. doi:10.1093/jxb/erv490.

Gašić, S. and B. Tanović. 2013. Biopesticide formulations, possibility of application and future trends. Pestic. Phytomed. (Belgrade), 28(2): 97-102. doi: 10.2298/PIF1302097G.

Gozalli, M. 2015. Karakteristik Tepung Kedelai dari Jenis Impor dan Lokal (Varietas Anjasmoro dan Baluran) dengan Perlakuan Perebusan dan Tanpa Perebusan. Skripsi. Fakultas Teknologi Pertanian. Universitas Jember. (On-line) http:// repository.unej.ac.id/bitstream/ handle/123456789/73466/111710101014-142.pdf?sequence $=1$ diakses pada tanggal 18 September 2017.

Gusnawaty, H.S., M. Taufik, L.O.S. Bande, dan A. Asis. 2017. Efektifitas beberapa medium untuk perbanyakan agens hayati Trichoderma sp. J. HPT Tropika 17(1): 7076.

Hanudin, A.A. Nawangsih, B. Marwoto, and B. Tjahyono. 2013. Komposisi formula biobakterisida berbahan aktif rizobacteri untuk pengendalian penyakit busuk lunak pada anggrek Phalaenopsis. Jurnal Hortikultura 23 (3): 224-254.

Heydari, A. and M. Pessarakli. 2010. A review on biological control of fungal plant pathogens using microbial antagonists. Journal of Biological Sciences 10(4): 273290. doi: 10.3923/jbs.2010.273.290.

Inácio, C.A., A.L.P.S. Rezende, L.S. KowataDresch, and J. Pedro Pimentel. 2017. Techniques for inoculation of Sclerotium rolfsii on Neomarica longifolia and Evolvulus pusillus in Brazil. EC Microbiology 9(3): 104-110.

Jaroszuk-Ściseł, J., R. Tyśkiewicz, A. Nowak, E. Ozimek, M. Majewska, A. Hanaka, K. Tyśkiewicz, A. Pawlik, and G. Janusz. 2019. Phytohormones (auxin, gibberellin) and ACC deaminase in vitro synthesized by the mycoparasitic Trichoderma DEMTkZ3A0 strain and changes in the level of auxin and plant resistance markers in wheat seedlings inoculated with this strain conidia. Int J Mol Sci. 20(19): 4923. doi: 10.3390/ijms20194923.

Jeger, M.J. and S.L.H. Viljanen-Rollinson. 2001. The use of the area under diseaseprogress curve (audpc) to asses quantitive disease resistance in crop cultivars. Theoretical Applied Genetics 102 (1): 32 40. doi: 10.1007/s001220051615.

Koike, S.T., M. Gaskell, C. Fouche, R. Smith, and J. Mitchell. 2000. Plant disease management for organic crops. ANR Publication 7252, University of California, Davis, CA.

Köhl, J., R. Kolnaar, and W.J. Ravensberg. 2019. Mode of action of microbial biological control agents against plant diseases: Relevance beyond efficacy. Front. Plant Sci., 19 July 2019 | https:// doi.org/10.3389/fpls.2019.00845.

Kredics, L., L. Manczinger, Z. Antal, Z.Pe'nzes, A. Szekeres, F. Kevei, and E. Nagy. 2005. In vitro water activity and $\mathrm{pH}$ dependence of mycelial growth and extracellular enzyme activities of Trichoderma strains with biocontrol potential. Journal of Applied Microbiology 96: 491-498. doi: 10.1111/j.13652672.2004.02167.x.

Kumar, G., A. Maharshi, J. Patel, A. Mukherjee, H.B. Singh, and B.K. Sarma. 201a7. Trichoderma: A potential fungal antagonist to control plant diseases. SATSA 
Mukhapatra Annual Technical Issue 21: 206 $-218$.

Leclerc, M., T. Doré, C.A. Gilligan, P. Lucas, and J.A.N. Filipe. 2014. Estimating the delay between host infection and disease (incubation period) and assessing its significance to the epidemiology of plant diseases. PLoS One 9(1): e86568. doi: 10.1371/journal.pone.0086568.

Mortimore, M. 2015. Dry land developers success stories from WestAfrica environment. J Biol Sci 45: 10-12.

Napitupulu, D.S., T. Karo-Karo, dan Z. Lubis. 2013. Pembuatan kue bolu dari tepung pisang sebagai substitusi tepung terigu dengan pengayaan tepung kedelai. $J$. Rekayasa Pangan dan Pertanian 1(4): 14-19.

Noordzij, M., F.W. Dekker, C. Zoccali, and K.J. Jager. 2010. Measures of disease frequency: Prevalence and incidence. Nephron - Clinical Practice, 115(1), 17-20. https://doi.org/10.1159/000286345.

Nurhidayati, S., A. Majid, dan P.A. Mihardjo. 2015. Pemanfaatan biofungisida cair berbahan aktif Trichoderma sp. untuk mengendalikan penyakit antraknosa (Colletotrichum sp.) pada cabai di lapang. J. Berkala Ilmiah Pertanian 1(1): 1-5.

Nzungize, J.R., F. Lyumugabe, J.P. Busogoro, and J.P. Baudoin. 2012. Pythium root rot of common bean: biology and control methods. Biotechnol. Agron. Soc. Environ 16(3): 405-413.

Roslee, N.R., F. Doni, K. Auma, Abzar, and W.M.W. Yusoff. 2017. Effect of Trichoderma spp. on mustard growth (Brassica juncea L.). Undergraduate Research Journal for Biomolecular Sciences and Biotechnology 1: 168-176.

Said, S.D. 2010. Model pertumbuhan biokontrol Trichoderma harzianum dalam medium cair. Hasil Penelitian Industri 23 (1): 28-37.

Shafique, H.A., S. Viqar, S. EhteshamulHaque, and M. Athar. 2016. Management of soil-borne diseases of organic vegetables. Journal of Plant Protection Research 56(3): 221-230. doi: 10.1515/jppr-2016-0043.

Shwab, E. And N. Keller. 2008. Regulation of secondary metabolite production in filamentous ascomycetes. Mycological Research 112: 225-30. doi: 10.1016/ j.mycres.2007.08.021.

Soesanto, L., B. Prakoso, E. Mugiastuti, dan R.F. Rahayuniati. 2015. Uji empat substrat cair organik terhadap pertumbuhan empat isolat Trichoderma sp. Kongres ke-23 dan Seminar Ilmiah Perhimpunan Fitopatologi Indonesia (PFI), Balai Uji Tearap Teknik dan Metode Karantina Pertanian, Bekasi, 11 -13 November 2015.

Soesanto, L., A. Hiban, and W.S. Suharti. 2019a. Application of Bio P60 and Bio T10 alone or in combination against stem rot of pakcoy. Journal of Tropical Horticulture 2 (2): 38-44. doi: 10.33089/jthort.v2i2.20.

Soesanto, L., E. Mugiastuti, and A. Manan. 2019b. Raw secondary metabolites of two Trichoderma harzianum isolates towards vacular streak dieback on cocoa seedlings. Pelita Perkebunan 35(1), 22-32.

Sutton, J.C., C.R. Sopher, T.N. Owen-Going, W. Liu, B. Grodzinski, J.C. Hall, and R.L. Benchimol. 2006. Etiology and epidemiology of Pythium root rot in hydroponic crops: current knowledge and perspectives. Summa Phytopathologica, 32 (4), 307-321. https://doi.org/10.1590/s010054052006000400001

Uruilal, C., A.M. Kalay, E. Kaya, dan A. Siregar. 2012. Pemanfaatan kompos ela sagu, sekam dan dedak sebagai medium perbanyakan agens hayati Trichoderma harzianum Rifai. J. Agrologia 1(1): 21-30.

Vinale, F., K. Sivasithamparam, E.L. Ghisalberti, S.L. Woo, M. Nigro, R. Marra, N. Lombardi, A. Pascale, M. Ruocco, S. Lanzuise, G. Manganiello, and M. Lorito. 2014. Trichoderma secondary metabolites active on plants and fungal pathogens. The Open Mycology Journal 8(Suppl-1, M5): 127-139.

Weller, D.M., J.M. Raaijimakers, B.B.M. Gardener, and L.S. Thomashow. 2002. Microbial populations responsible for specific soil suppressiveness to plant pathogens. Annual Review of Phytopathology 40: 309-348

Zaidi, A.A., E.A. Elhag, S.H., Al-Otaibi and M.B. Baig. 2011. Negative effects on the environment and the farmers awareness in Saudi Arabia. The Journal of Animal and Plants Sciences 21(3): 605-611.

Zehra, A., M.K. Dubey, M. Meena, and R.S. Upadhyay. 2017. Effect of different environmental conditions on growth and sporulation of some Trichoderma species. Journal of Environmental Biology 38: 197203. 